\title{
MIASTO I WOJNA ZABYTKI ARCHEOLOGICZNE W ZBIORACH MUZEUM POLIN
}

Streszczenie. W kolekcji Muzeum Historii Żydów Polskich w Warszawie oprócz dzieł sztuki, pamiątek historycznych czy judaików można odnaleźć także ruchome zabytki archeologiczne. Część z tych obiektów została zebrana w trakcie badań wykopaliskowych prowadzonych w 1998 i 2009 r. na terenie, na którym obecnie znajduje się muzeum. Pozostałe to przypadkowe znaleziska. Celem artykułu jest zarówno pokazanie specyfiki obiektów wykopanych z gruzowiska getta warszawskiego, jak i próba naświetlenia historii, którą owe przedmioty nam opowiadają. Ponieważ nie jesteśmy w stanie uzyskać informacji dotyczących "biografii rzeczy" wydobytych z ziemi od ich pierwotnych właścicieli, bezcenne źródło wiedzy na temat historii obiektów, a także osób, do których dawniej należały, stanowi dokumentacja wykonana podczas badań wykopaliskowych. Omawiane w tekście zabytki archeologiczne są świadectwem życia i codzienności mieszkańców getta, jednocześnie przypominając nam o ich tragicznych losach.

Słowa kluczowe: archeologia, muzealnictwo, Żydzi, druga wojna światowa, getto warszawskie, znaleziska, eksponaty muzealne

\section{Wstęp}

Muzeum Historii Żydów Polskich powstało w przestrzeni stanowiącej dawniej część getta warszawskiego - symbolicznej dla upamiętnienia tej traumatycznej części historii społeczności polskich Żydów. Obiekty odnalezione podczas badań wykopaliskowych prowadzonych dwukrotnie na zlecenie Stowarzyszenia Żydowski Instytut Historyczny (1998 i 2009) na terenie działki wyznaczonej pod budowę gmachu muzeum stały się ważną częścią jego kolekcji. Oprócz przedmiotów wydobytych z ziemi w czasie eksploracji archeologicznej w zbiorach znajdują się także przypadkowe znaleziska przynoszone spontanicznie przez darczyńców, którzy natknęli się na nie, spacerując po dzielnicy. 


\section{Powstanie muzeum}

Inspiracją dla utworzenia Muzeum Historii Żydów Polskich było otwarcie Muzeum Holokaustu w Waszyngtonie w 1993 r. Jednym z gości zaproszonych na tę uroczystość była bowiem Grażyna Pawlak, dyrektor do spraw Organizacji i Informacji Żydowskiego Instytutu Historycznego w Warszawie. Po powrocie do kraju zaproponowała na forum stowarzyszenia stworzenie w Polsce muzeum, które będzie prezentować historię polskich Żydów. Inicjatywa zakładała jednak otwarcie „muzeum życia”, które nie skupiałoby się jedynie na Holokauście, ale w sposób holistyczny ukazywałoby losy społeczności żydowskiej na polskich ziemiach. Narracja nowego muzeum miała objąć tysiąc lat historii polskich Żydów, od momentu pierwszych wzmianek w źródłach historycznych do współczesności ${ }^{1}$.

Już w 1993 r. powołano Międzynarodowy Honorowy Komitet upowszechniający ideę projektu muzeum. Komitetowi przewodniczyli Chaim Herzog (były prezydent Izraela) oraz Ronald S. Lauder (biznesmen i filantrop, prezes Fundacji Laudera). W skład komitetu w kolejnych latach weszli przywódcy światowych organizacji żydowskich i politycy, tacy jak Jan Nowak-Jeziorański, Jan Karski czy Zbigniew Brzeziński. Dnia 17 kwietnia 1997 r. decyzją ówczesnego prezydenta Miasta Stołecznego Warszawy Marcina Święcickiego Stowarzyszeniu ŻIH została przekazana działka pod budowę muzeum. Gmach instytucji miał stanąć na warszawskim Muranowie, w pobliżu pomnika Bohaterów Getta Warszawskiego. Teren ten jest przestrzenią o wymiarze symbolicznym nie tylko ze względu na położenie na terenie dawnego getta warszawskiego, ale także przez to, że na części działki znajdowały się wybudowane w XVIII w. Koszary Artylerii Koronnej. W czasie funkcjonowania getta zorganizowano w tym budynku Areszt Centralny, a w sierpniu 1942 r. stał się on ostatnią siedzibą Rady Żydowskiej (Judenratu). Część działki wyznaczonej pod muzeum znajduje się w miejscu, gdzie dawniej przebiegała ulica Dzika (dziś ul. Ludwika Zamenhofa) i stały domy mieszkalne².

W 1998 r. rozpoczęły się prace programowe związane z koncepcją wystawy stałej oraz profilem przyszłej działalności muzeum. Rozpoczęło się także

${ }^{1}$ Historia: od Idei, przez OHEL do Muzeum POLIN, https://www.polin.pl/pl/about-the-museum/historia-od-idei-przez-ohel-do-muzeum-polin (dostęp: 20 X 2020).

2 R. PiątKowska, P. Kaniecki, Obiekty „muranowskie”, [w:] „Tu Muranów. Dzielnica pod gruzami", red. K. RADECKA-MiKULICZ, Warszawa 2020, s. 42. 
tworzenie kolekcji, do której włączono obiekty wydobyte z ziemi podczas pierwszych badań archeologicznych prowadzonych na działce ${ }^{3}$. W kolejnym roku powołana została Rada Muzeum. Jej przewodniczącym został Marian Turski (przewodniczący Stowarzyszenia ŻIH), a wśród członków znalazł się m.in. Władysław Bartoszewski (pełniący wówczas funkcję ministra spraw zagranicznych). Kolejny przełom dla muzeum nastąpił w styczniu 2005 r., kiedy ówczesny prezydent Warszawy Lech Kaczyński w porozumieniu z Ministerstwem Kultury powołał do życia muzeum w formule partnerstwa publiczno-prywatnego. Pierwszym dyrektorem POLIN został Jerzy Halbersztadt, który wcześniej pełnił funkcję dyrektora Programu Polskiego Muzeum Holokaustu w Waszyngtonie.

W listopadzie 2006 r. nastąpiła inauguracja Ohelu (hebr. 'namiot') - projektu artystycznego w formie błękitnego, otwartego namiotu, który swoją formą nawiązywał do ścian krzywoliniowych głównego holu w projekcie budynku muzeum. Już w tym czasie odwiedzający Ohel mieszkańcy dzielnicy oraz turyści poczęli w sposób spontaniczny przynosić prawnikom powstającego muzeum zabytki. W dużej części były to przypadkowe znaleziska archeologiczne, które wyzierały z wykopów przy każdej okazji naruszenia ziemi Muranowa. Na datę otwarcia wystawy stałej wyznaczono 19 kwietnia 2013 r. Wybór terminu był związany z obchodami siedemdziesiątej rocznicy wybuchu powstania w getcie warszawskim. Uroczyste otwarcie wystawy stałej zatytułowanej 1000 lat historii Żydów polskich przez prezydentów Polski (Bronisława Komorowskiego) i Izraela (Re’uwena Riwlina) odbyło się ponad rok później - 28 października 2014 r. ${ }^{4}$

\section{Badania archeologiczne pod budowę muzeum POLIN}

Getto, w którym miała się znaleźć żydowska ludność Warszawy, zostało utworzone przez władze niemieckie w Warszawie 2 października 1940 r. Miesiąc później, 16 listopada getto zostało zamknięte, a ponad 400 tys. polskich Żydów zostało oddzielonych od reszty społeczeństwa ceglanym murem. Getto warszawskie było największe w całej Europie. Dnia 22 lipca 1942 r. rozpoczęły się akcja likwidacyjna getta i wywóz zamkniętej w nim ludności do obozu zagłady w Treblince. Reakcją na akcję likwidacyjną był wybuch powstania w getcie,

\footnotetext{
3 Ibidem.

${ }^{4}$ Historia: od Idei...
} 
które trwało od 19 kwietnia do 16 maja 1943 r. Powstanie pochłonęło tysiące istnień ludzkich oraz przyczyniło się do niemal całkowitego zniszczenia dzielnicy. Po stłumieniu buntu w getcie warszawskim resztki znajdujących się dawniej w tym miejscu budynków zostały wyburzone, a przedmioty codziennego użytku, które pozostały po dawnych mieszkańcach dzielnicy, przemieszały się z powstałym gruzem ${ }^{5}$.

Prace wykopaliskowe podjęte dwukrotnie (1998 i 2009) w miejscu, gdzie planowano wznieść Muzeum Historii Żydów Polskich, miały charakter badań ratowniczych. Ich celem było wydobycie zalegających w ziemi śladów dawnego życia dzielnicy, o której mieszkańcach miała opowiadać część wystawy stałej powstającej instytucji. Pierwsze badania związane z projektem budowy muzeum zostały przeprowadzone w 1998 r. i objęły wówczas zachodnią część posesji muzealnej, gdzie odkryto fundamenty ścian dawnych Koszar Artylerii Koronnej (druga połowa XVIII w.), studzienkę i odcinki ceglanych kanałów ściekowych (druga polowa XIX w.), dawną nawierzchnię chodnika i jezdni ul. Dzikiej oraz mury i zasypiska piwnic kamienicy znajdującej się niegdyś przy ul. Dzikiej 21. Z nawarstwień wykopowych zebrano wówczas liczne materiały zabytkowe datowane na okres od połowy XVII do połowy XX w. W zbiorze znalazły się m.in.: ceramika naczyniowa i budowlana, kafle, przedmioty szklane i metalowe (w tym maszyna do szycia Singer), resztki pokonsumpcyjne (kości zwierzęce), fragmenty papieru, przedmiotów kościanych oraz z tworzywa sztucznego ${ }^{6}$.

Kolejny raz ziemia na terenie przeznaczonym pod budowę muzeum została odsłonięta w 2009 r. Badania trwające od 12 sierpnia do 9 października obejmowały nadzór archeologiczny prac ziemnych związanych z budową nowej siedziby muzeum POLIN. Prace rozpoczęły się od szerokoprzestrzennego odsłonięcia ziemi pod betonową wylewkę i podpiwniczenie powstającego budynku za pomocą ciężkiego sprzętu (koparek). Podczas nadzoru udało się uratować: 208 fragmentów i całych naczyń ceramicznych, 124 fragmenty naczyń szklanych, 119 przedmiotów metalowych oraz 16 fragmentów wykonanych z innych surowców?

5 K. RadeCKa-Mikulicz, Muranów-warstwy życia, warstwy pamięci, [w:] „Tu Muranów. Dzielnica pod gruzami”, s. 10.

6 R. CĘDROwSKI, Sprawozdanie z przeprowadzenia badań archeologicznych zwiazanych z budowa Muzeum Historii Żydów Polskich w Warszawie, Warszawa 2009, s. 1.

7 Ibidem, s. 3-4. 


\section{Archeologia miejsc pamięci}

Wykopaliska prowadzone na terenie przeznaczonym pod budowę muzeum POLIN wpisują się w nurt archeologii publicznej, czyli takiej, której wyniki badawcze są dostępne szerszej publiczności i stanowią przedmiot zainteresowania osób niebędących badaczami (w tym wypadku mieszkańców dzielnicy Muranów czy miasta Warszawy) ${ }^{8}$. Badania wykopaliskowe obejmujące swoją tematyką wiek XX określa się mianem archeologii współczesności. Rozwój tej dziedziny wiąże się z potrzebą udokumentowania zbrodni dokonanych na przestrzeni ostatniego stulecia. Pierwsze badania współczesnych stanowisk prowadzono w latach sześćdziesiątych XX w. Ich celem było odnalezienie materialnych reliktów związanych z ludobójstwem dokonanym w czasie drugiej wojny światowej, a tym samym wsparcie pracy śledczych ${ }^{9}$. Z czasem ta dziedzina archeologii zyskuje coraz szerszy wymiar, zarówno przestrzenny, jak i czasowy. Badania z zakresu archeologii współczesności obejmują bowiem nie tylko stanowiska związane z drugą wojną światową, ale i bliższymi chronologicznie ludobójstwami, jak te, do których doszło w Kambodży (1975-1979), Rwandzie (1994) czy Srebrenicy (1995).

Badania współczesnych stanowisk archeologicznych obejmujące miejsca naznaczone traumą (miejsca ludobójstwa/kaźni, tereny dawnych gett i obozów koncentracyjnych) określa się także mianem archeologii miejsc pamięci ${ }^{10}$. Ważne w kontekście badań archeologicznych prowadzonych w miejscach pamięci (i nie tylko) jest także zestawienie wydobytych obiektów z innymi źródłami. W wypadku stanowisk współczesnych oprócz źródeł historycznych możliwe jest wykorzystanie również relacji naocznych świadków wydarzeń, co stanowi unikatowe źródło informacji. W odniesieniu do relacji ustnych należy jednak pamiętać, że nie zawsze muszą być one zgodne z prawdą historyczną. Upływ czasu, ładunek emocjonalny oraz inne czynniki zewnętrzne i wewnętrzne mogą wpływać na kształt opowieści świadków, co nie czyni ich jednak mniej wartościowymi z perspektywy muzealników.

${ }^{8}$ K. KARSKI, M. ŚMIETANA, Muzeum - Archiwum Pamięci. Uwagi na temat roli materiatów archeologicznych w Muzeach - Archiwach Pamięci na przyktadzie KL Plaszow, „Folia Praehistorica Posnaniesia" 2009, t. 24, s. 290.

9 K. Karski, Kl Plaszow. Archeologia Miejsca Pamięci, Kraków 2019, s. 20.

${ }^{10}$ Ibidem, s. 19-21. 
Po zakończeniu wykopalisk w miejscach pamięci zwykle pozostawiona zostaje jakaś forma upamiętnienia tego, co się w tym miejscu wydarzyło. W zależności od warunków może to być tablica pamiątkowa czy pomnik, a nawet instytucja, do której trafią wydobyte obiekty i której zadaniem będzie podtrzymywanie i upowszechnianie pamięci o miejscu, jak np. muzeum powstające na miejscu KL Plaszow ${ }^{11}$. Innym sposobem upamiętnienia jest udostępnienie części miejsca pamięci odwiedzającym. Za przykład tego można podać chociażby idee związane z udostępnieniem odsłoniętej podczas badań wykopaliskowych prowadzanych w 2020 r. kryjówki na cmentarzu żydowskim przy ul. Okopowej w Warszawie. Jeden z pomysłów zakłada osłonięcie wykopu przezroczystą płytą, co umożliwi odwiedzającym wgląd w to, w jakich warunkach ukrywali się przebywający tam $\dot{Z} y d z i^{12}$.

Obiekty wydobyte podczas prac wykopaliskowych prowadzonych na terenie przeznaczonym pod budowę muzeum POLIN trafiły do magazynów instytucji, która stanęła w miejscu ich odnalezienia. Miejsce to nie zostało zresztą wybrane przypadkowo. Narracja muzeum obejmuje bowiem 1000 lat historii Żydów polskich, których nieodłączną, acz bolesną część stanowi Zagłada. W tym kontekście wzniesienie gmachu instytucji mającej zachować i upowszechniać tę historię na gruzach getta warszawskiego, w pobliżu pomnika jego bohaterów, ma wymiar symboliczny.

\section{Zabytki archeologiczne w kolekcji POLIN}

W przeciwieństwie do pamiątek osobistych, które stanowią najliczniejszągrupę obiektów w zbiorach muzeum POLIN, przedmioty wykopane z ziemi trafiają do niego bez „biografii”. Rzeczy bowiem, jako „wytwory zarówno natury, jak i człowieka, są w pisane w ludzką kulturę w taki sposób, że reprezentują stosunki społeczne wewnątrz kultury, zastępując innych ludzi, przenosząc wartości, idee i uczucia"13. Pamiątki przyniesione do muzeum przez osoby, które dawniej

${ }^{11}$ M. Bednarek, K. Karski, M. Śmietana, Miejsce Pamięci KL Plaszow. Raport za okres 2016 2017, Kraków 2017, s. 9-11.

12 A. Janus, N. Romnik, Projekt upamiętnienia kryjówki na cmentarzu żydowskim przy ul. Okopowej w Warszawie, Warszawa 2021, s. 33-45.

13 T. DANT, Kultura materialna w rzeczywistości spotecznej. Wartości, dziatania, style życia, przekł. J. BARAŃSKI, Kraków 2007, s. 13. 
ich używały (lub ich spadkobierców), najczęściej nie przedstawiają większej wartości materialnej. Dla osób pracujących w muzeum narracyjnym (takim jak POLIN) największą wartość stanowi jednak to, co przedmioty te sobą reprezentują, jakich wydarzeń były „świadkami”, jaki ładunek emocjonalny w sobie noszą. Powiązanie z przedmiotem tych wszystkich informacji możliwe jest jedynie dzięki przeprowadzeniu pogłębionego wywiadu z darczyńcą. Darowany przedmiot staje się w przestrzeni muzealnej narzędziem do przekazywania jego opowieści, czy to podczas prezentacji pamiątki na wystawie, czy przez umieszczenie zdjęcia z opisem na stronie internetowej bądź w publikacji naukowej.

Jaką wartość dla muzeum opierającego swoją kolekcję na opowieściach przekazywanych za pomocą przedmiotów stanowią zatem obiekty wyciągnięte z ziemi? W tym miejscu należy wyraźnie rozróżnić dwa rodzaje ruchomych zabytków znajdujących się w kolekcji Muzeum Historii Żydów Polskich. Pierwsza z wspomnianych powyżej kategorii to zabytki wydobyte podczas prac wykopaliskowych pod nadzorem archeologów. Obszar, gdzie pracują archeolodzy, podzielony jest na stanowiska, dla których wcześniej przygotowuje się dokumentację merytoryczną pozwalającą (w miarę możliwości) na określenie, co znajdowało się wcześniej na terenie wykopu i czego można się ewentualnie spodziewać. Na każdym etapie eksploracji stanowiska oraz znajdowane na nich obiekty są dokumentowane (dokumentacja fotograficzna, rysunkowa, dziennik badań). Prowadzona jest także dokumentacja związana ze stratygrafią stanowiska (określeniem warstw kulturowych odpowiadających kolejnym okresom), na którym obiekty są znajdowane. Po wydobyciu każdy obiekt zostaje wstępnie oczyszczony, opatrzony metryczką oraz spakowany w woreczek strunowy. Tego rodzaju zabytki archeologiczne trafiają więc do muzeum z pełną dokumentacją określającą miejsce znalezienia, ich przybliżony wiek (na podstawie określenia warstwy kulturowej, w której zostały znalezione) oraz stan zachowania w momencie znalezienia.

Martyna Milewska, pod której kierownictwem prowadzone były pierwsze badania wykopaliskowe na terenie wyznaczanym pod budowę muzeum (1998), podała, że odnalezione wówczas obiekty, mimo braku informacji o tym, do kogo konkretnie należały (jak w wypadku pamiątek osobistych), posiadały silny ładunek emocjonalny. $Z$ wykopu prowadzonego na terenie gruzowiska getta wyciągnięte zostały bowiem „przedmioty, które wszyscy mamy: grzebyk do upinania 
włosów, słoiczek do kremu, łyżka. Za tym kryje się człowiek, każdy taki przedmiot mówi coś o człowieku. O ludziach, którzy byli tuż za rogiem, którzy tu mieszkali. I o tym, jaki był ich koniec"14.

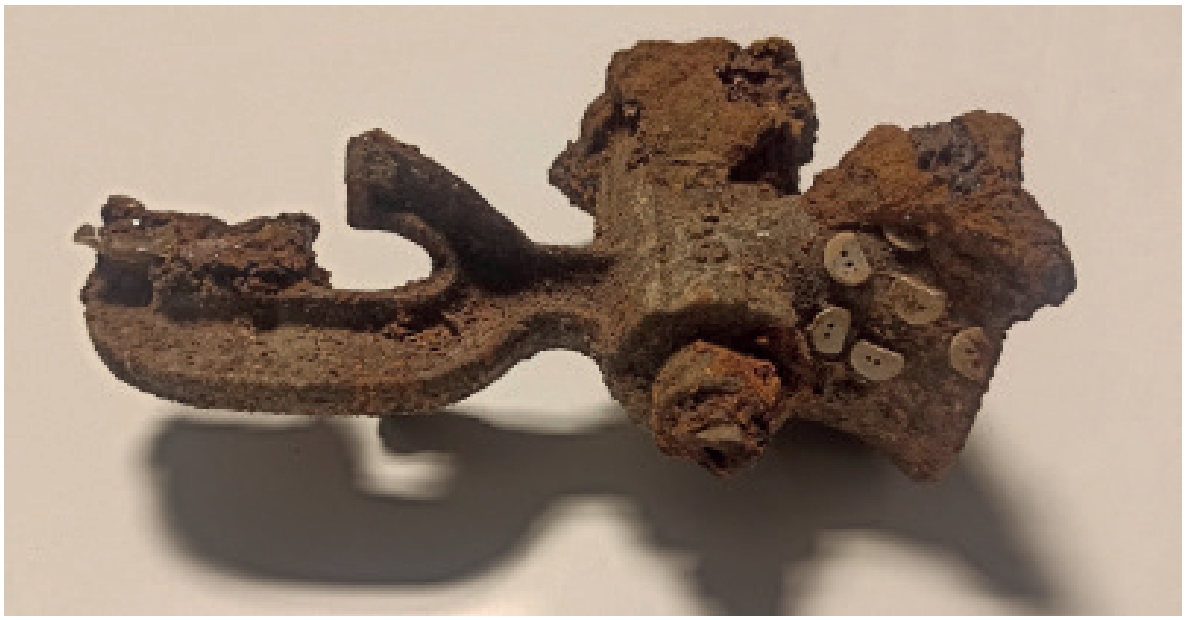

Ryc. 1. Maszynka do mięsa wydobyta podczas badań archeologicznych prowadzonych na placu przeznaczonym pod budowę muzeum (źródło: kolekcja Muzeum Historii Żydów Polskich POLIN, fot. M. Frączkiewicz)

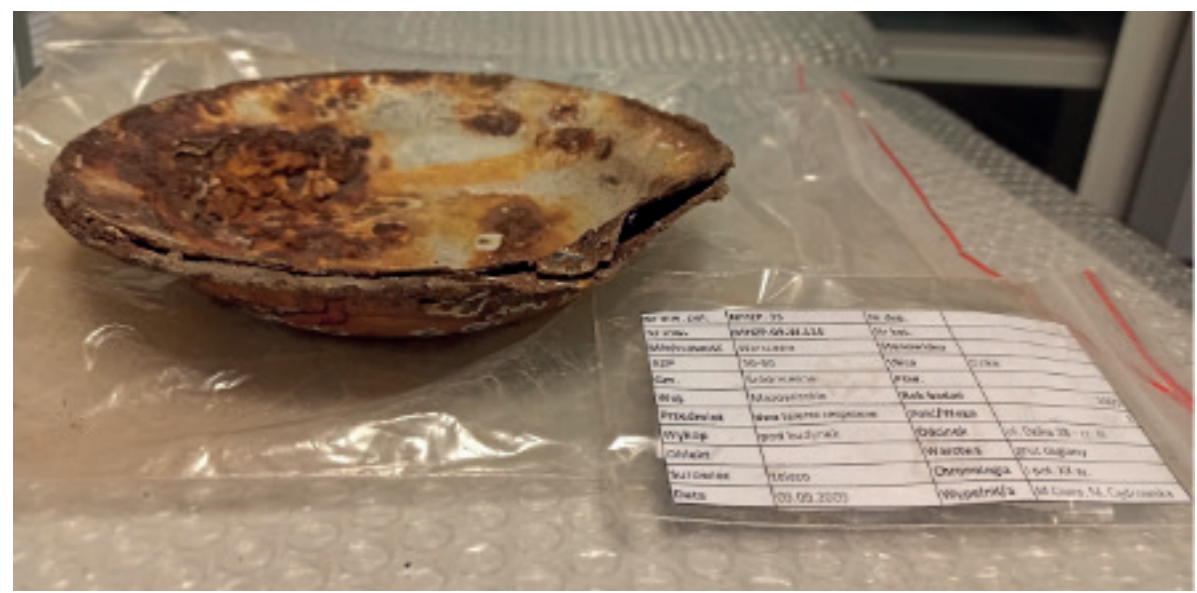

Ryc. 2. Dwa stopione ze sobą talerze wydobyte podczas badań archeologicznych prowadzonych na placu przeznaczonym pod budowę muzeum (źródło: kolekcja Muzeum Historii Żydów Polskich POLIN, fot. M. Frączkiewicz)

14 M. Milewska, P. Kaniecki, Archeologia o Muranowie, [w:] „Tu Muranów. Dzielnica pod gruzami”, s. 36. 
Obiekty odnalezione podczas wykopalisk archeologicznych stanowily ważną część wystawy czasowej Tu Muranów (26 czerwca 2020 - 22 marca 2021) opowiadającej o trudnej historii dzielnicy. Wśród prezentowanych obiektów można zobaczyć przedmioty, których kształt od razu przywodzi na myśl obraz trawiącego getto pożaru. Za przykład można podać chociażby powyginane od żaru sztućce, maszynkę do mięsa z wtopionymi w nią pod wpływem wysokiej temperatury kolorowymi guzikami (ryc. 1) czy talerze, które ogień stopił ze sobą (ryc. 2).

$\mathrm{Na}$ wystawie prezentowane są także fragmenty ceramiki i szkła oraz metali. Ze względu na właściwości tworzyw niektóre płytki, kafle czy butelki zachowały się w całości, inne fragmentarycznie. Na niektórych z nich widać również miejscowe zniekształcenia, które powstały pod wpływem wysokiej temperatury w czasie pożaru. Większość metali uległa także silnej korozji w wyniku wieloletniego zalegania w ziemi. Do ciekawszych obiektów należą m.in. promująca wystawę łyżka zrośnięta z korzeniem, która w sposób symboliczny ukazuje fakt zawłaszczenia tych przedmiotów (wytworów człowieka) przez naturę. Bodaj najbardziej odwołującą się do emocji współczesnego widza grupę stanowią przedmioty osobiste, takie jak klucz, który służył komuś do otwierania domu, połamane okulary w modnej obecnie szylkretowej oprawce (ryc. 3) czy sznur stopionych ze sobą paciorków, które niegdyś zdobiły szyję jakiejś elegantki (ryc. 4). Kurator wystawy Kamila Radecka-Mikulicz zwraca jednak uwagę odbiorcy na fakt, że wszystkie prezentowane obiekty to: „przedmioty osierocone, o których użytkownikach nie wiemy nic lub bardzo niewiele. (...) Mimo to, przedmioty znaczą bardzo wiele, są przecież jedynymi świadectwami życia ludzi, którym towarzyszyły na co dzień. Jednocześnie są świadectwami ich zagłady"15.

Drugą grupę obiektów archeologicznych znajdujących się w zbiorach $\mathrm{Mu}-$ zeum Historii Żydów Polskich stanowią przypadkowe znaleziska archeologiczne. To najczęściej obiekty, które darczyńcy (zwykle mieszkańcy dzielnicy) znajdują na hałdach ziemi zalegającej na chodnikach w wyniku prac ziemnych, takich jak wymiana rur na osiedlu czy wykop pod fundamenty nowego budynku. Wielu z darczyńców latami zbierało tego rodzaju obiekty z poboczy i trawników, by w końcu przekazać swoje zbiory do muzeum. Jak wcześniej wspomniano, pierwszym impulsem do przekazania swoich zbiorów pracownikom POLIN stało się otwarcie w 2006 r. Ohelu promującego powstające w tym miejscu muzeum oraz ogłoszenie towarzyszącego temu wydarzeniu programu zbierania pamiątek.

\footnotetext{
${ }^{15}$ K. Radecka-Mikulicz, op. cit., s. 10.
} 


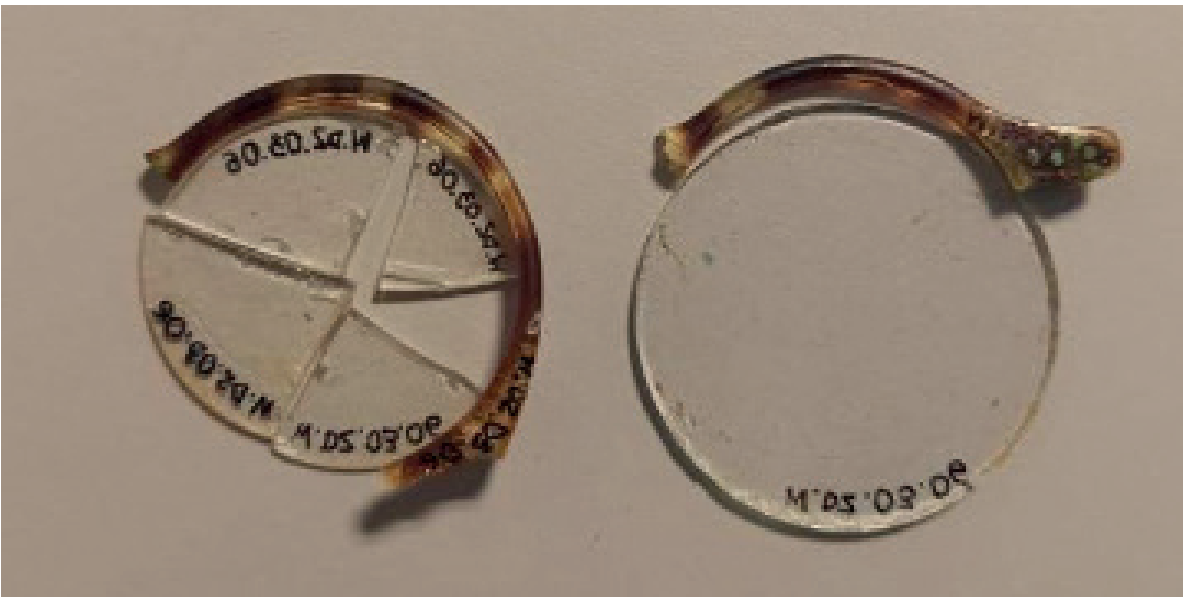

Ryc. 3. Fragmenty okularów wydobyte podczas badań archeologicznych prowadzonych na placu przeznaczonym pod budowę muzeum (źródło: kolekcja Muzeum Historii Żydów Polskich POLIN, fot. M. Frączkiewicz)

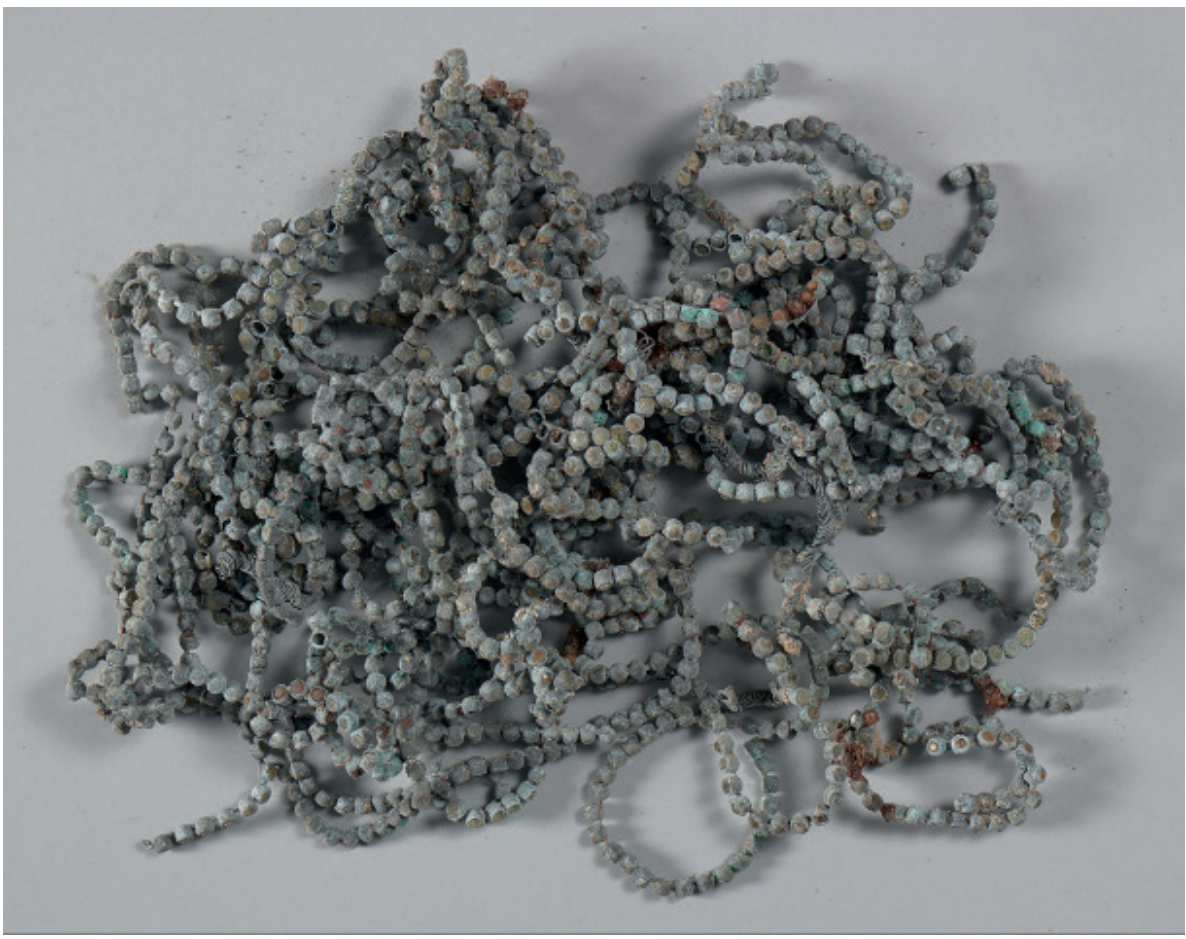

Ryc. 4. Sznur stopionych ze sobą szklanych paciorków wydobyty podczas badań archeologicznych prowadzonych na placu przeznaczonym pod budowę muzeum (źródło: kolekcja Muzeum Historii Żydów Polskich POLIN, fot. M. Frączkiewicz) 
W wypadku tego rodzaju przedmiotów nie ma jednak pewności, z jakiego miejsca dokładnie pochodzą ani na jakiej głębokości się znajdowały (najczęściej warstwy ziemi są bowiem ściągane za pomocą koparki, co powoduje ich przemieszanie). Dodatkowo nie ma pewności, czy ziemia, w której znajdowane są obiekty, nie została przywieziona z innego miejsca na potrzeby budowy drogi czy stojących przy niej budynków. Znaleziony w niej fragment ceramiki może zatem równie dobrze pochodzić z podwarszawskiej piaskowni.

Pierwsze przypadkowe znaleziska archeologiczne były odkrywane na $\mathrm{Mu}-$ ranowie już podczas odgruzowywania dzielnicy w pierwszych latach po zakończeniu drugiej wojny światowej. Jeden z pierwszych obiektów w kolekcji POLIN został znaleziony w 1953 r. u zbiegu ul. Karmelickiej i Pawiej, w trakcie tego rodzaju prac wykonywanych w ramach czynu społecznego z okazji święta 1 Maja przez dwoje studentów Wydziału Fizyki Uniwersytetu Warszawskiego. Wspomniany obiekt to emaliowany szyld gabinetu dentystki dr Berty Kacenelenbogen $(\text { ryc. } 5)^{16}$.

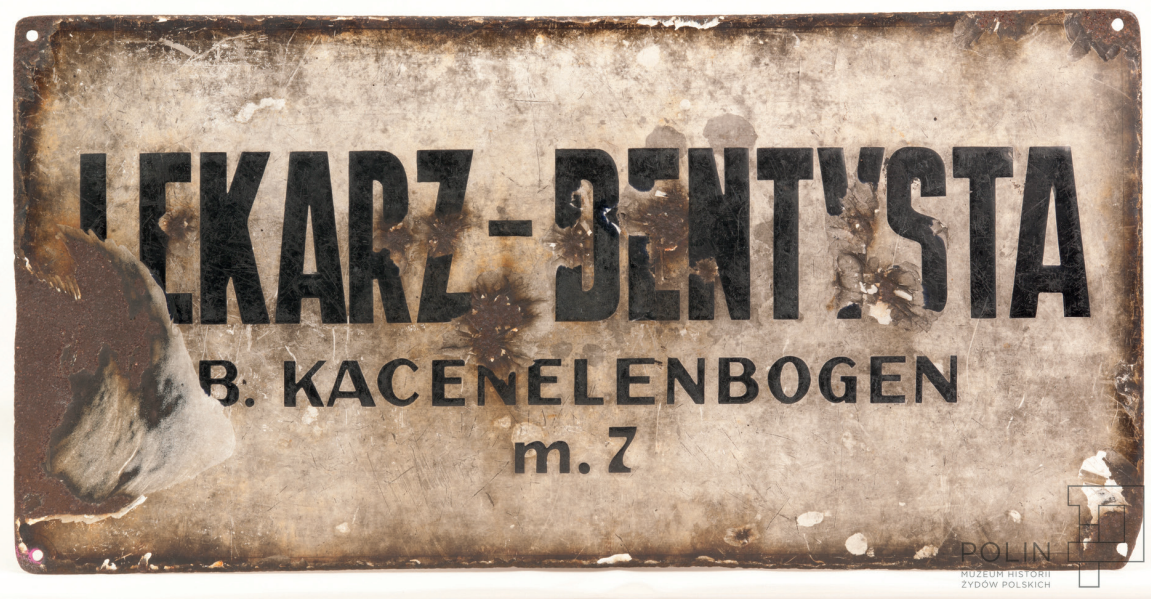

Ryc. 5. Szyld gabinetu dentystki dr Berty Kacenelenbogen znaleziony podczas odgruzowywania Muranowa w 1953 r. (MPOLIN-M493)

Początkowo studenci uznali ten przedmiot za kawałek zwykłej blachy ocynkowanej, która w tamtym czasie mogła okazać się cennym materiałem konstrukcyjnym. Znalazca przekazał więc blachę ciotce mieszkającej w Legionowie, aby ta wykorzystała ją podczas remontu. Po oczyszczeniu przedmiotu okazało się

16 http://judaika.polin.pl/dmuseion/docmetadata?id=52\&show_nav=true (dostęp: 15 X 2020). 
jednak, że blacha to szyld praktyki dentystycznej, a oczom zebranych ukazały się nazwisko i numer mieszkania dentystki. Wykorzystanie przedmiotu w pierwotnym pragmatycznym celu zostało wówczas uznane przez rodzinę za niestosowne. Szyld został przez nią przechowany jako swego rodzaju „relikwia” z zagłady. W 2006 r., po przeczytaniu w jednej z gazet informacji o nowo powstającym muzeum, darczyńca postanowił przekazać obiekt do zbiorów POLIN.

Niezwykle pomocna dla muzealników jest możliwość przeprowadzenia wywiadu z darczyńcą, który może podzielić się w nim swoją motywacją. Wiele z osób przekazujących do zbiorów przypadkowe znaleziska przyznaje bowiem, że zbierało ślady po życiu, którego już nie ma, przez dłuższy czas, zanim przynieśli przedmioty do otwierającego się muzeum. Hanna Nowak-Radziejwoska, która przekazała do kolekcji zbiór 7 fragmentów porcelany zebranych na $\mathrm{Mu}$ ranowie (ryc. 6), wspomina, że: „rowy były niezabezpieczone, kompletnie bez żadnej ochrony. To też mi dało do myślenia (...) Wskakiwałam i po prostu szukałam... Naraz okazywało się, że między tymi spalonymi cegłami są po prostu resztki codziennego życia, resztki tego świata"17.

Zabieranie do domu fragmentów ceramiki, metalu czy szkła, które stale wystają z hałd ziemi zalegających na chodnikach podczas wykonywanych na terenie Muranowa prac ziemnych, wynika, zdaniem darczyńców, z potrzeby serca. Jest sposobem na uratowanie materialnych śladów po dawnym życiu dzielnicy przed ponownym zagrzebaniem w ziemi przez koparki. O potrzebie zachowania pamięci o dawnych mieszkańcach dzielnicy piszą także badacze działacze społeczni związani z Muranowem, jak np. Beata Chomątowska - autorka książki Stacja Muranów: „Zaglądamy w wykopy ku zdziwieniu robotników wymieniających kable, wypatrując kawałków przedwojennych cegieł, popękanych butelek po wodzie kolońskiej, gwoździ i guzików - śladów poprzedniego życia”18.

Omawiając przypadkowe znaleziska archeologiczne znajdujące się w zbiorach muzeum POLIN, należy wymienić także kolaż wykonany przez darczyńcę z fragmentów ceramicznych płytek znalezionych w 2000 r. (ryc. 7). Przez zebranie i przyklejenie do drewnianej ramy dosłownie potłuczonych fragmentów dawnego życia autorka (niebędąca profesjonalną artystką) chciała zachować od zapomnienia świat, po którym zostały już tylko podobne okruchy gliny i metalu.

17 H. Nowak-Radziejwoska, P. Kaniecki, Porcelana, [w:] „Przynoszęrzecz, przynoszę historię”, red. J. PAWLAK, P. Kaniecki, Warszawa 2016, s. 200.

18 B. Chomątowska, Stacja Muranów, Wołowiec 2016. 


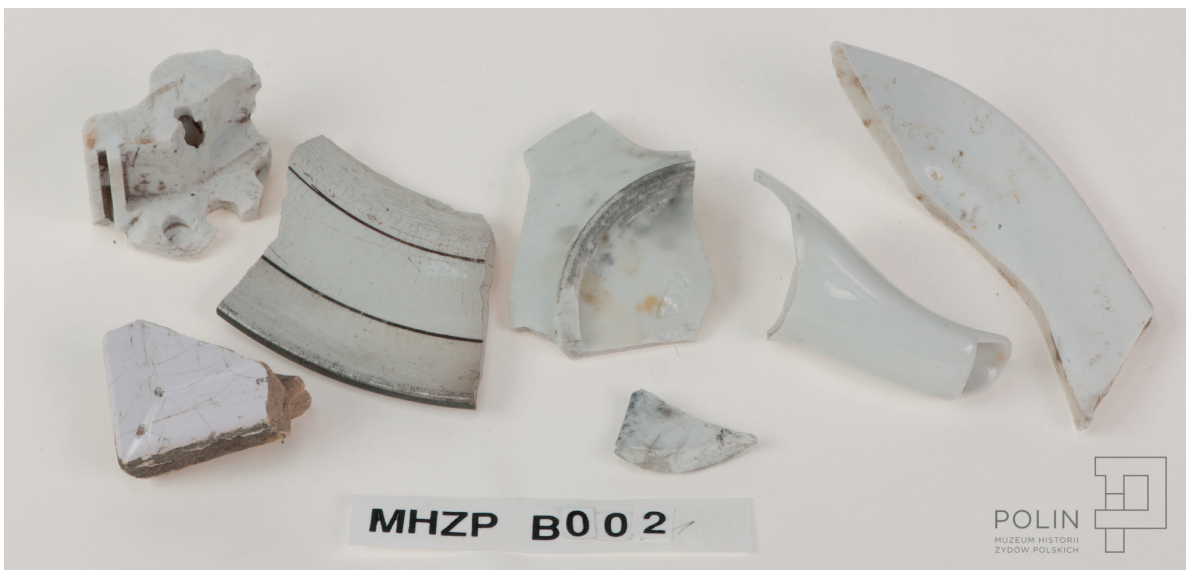

Ryc. 6. Fragmenty porcelany zebrane z wykopów ziemnych na Muranowie (MHZP-B2/1-7)

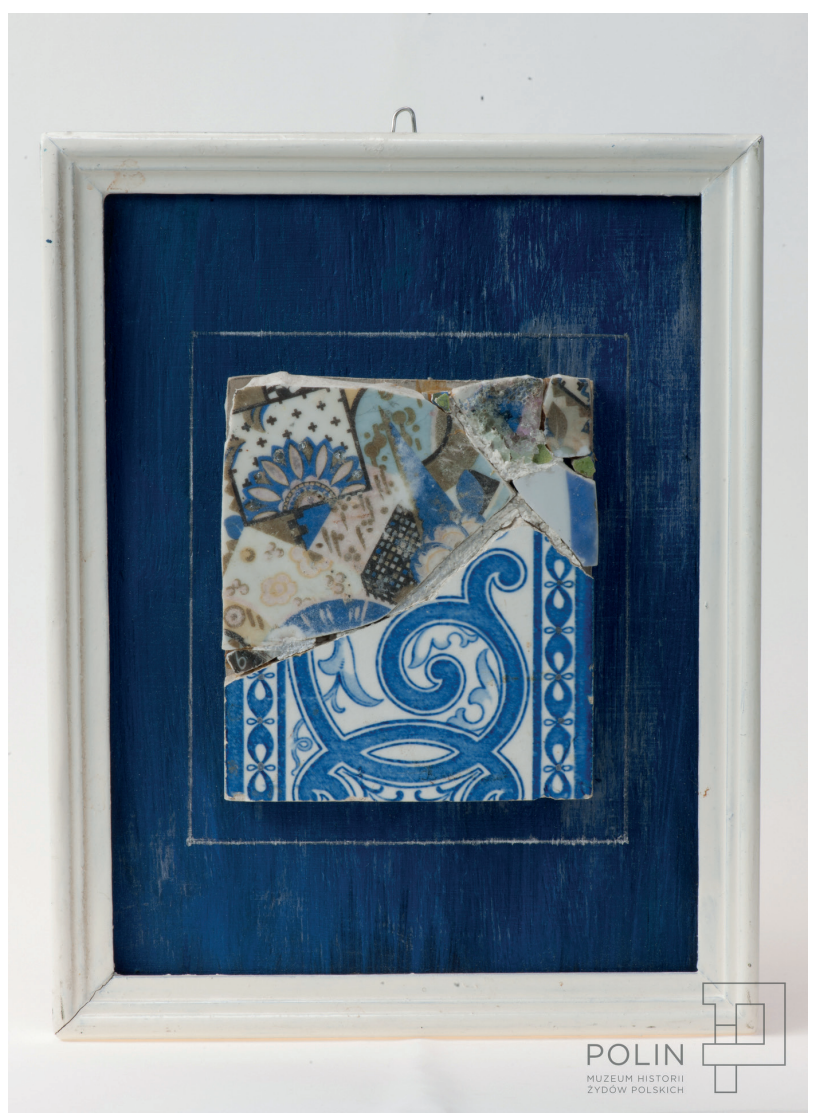

Ryc. 7. Kolaż wykonany z płytek ceramicznych znalezionych na terenie Muranowa (MHZP-B210) 
Zgłębiając temat przypadkowych znalezisk archeologicznych, trzeba jednak pamiętać, że zgodnie z ustawą o ochronie zabytków i opiece nad zabytkami z 23 lipca 2003 r. (rozdział 3, art. 33) należy niezwłocznie zgłosić każde tego rodzaju znalezisko odpowiednim służbom:

Kto przypadkowo znalazł przedmiot, co do którego istnieje przypuszczenie, iż jest on zabytkiem archeologicznym, jest obowiązany, przy użyciu dostępnych środków, zabezpieczyć ten przedmiot i oznakować miejsce jego znalezienia oraz niezwłocznie zawiadomić o znalezieniu tego przedmiotu właściwego wojewódzkiego konserwatora zabytków, a jeśli nie jest to możliwe, właściwego wójta (burmistrza, prezydenta miasta) ${ }^{19}$.

Konieczność każdorazowego zgłoszenia znaleziska odpowiednim służbom zniechęca wielu darczyńców do przekazania przypadkowych znalezisk archeologicznych muzeum.

\section{Zabytki archeologiczne pochodzące z miejsc pamięci w zbiorach innych muzeów}

Wiele muzeów podejmujących temat Zagłady prowadzi projekty obejmujące badania archeologiczne lokalnych miejsc pamięci, a także przyjmuje do swoich zbiorów wydobyte podczas badań obiekty. Do ważniejszych przykładów wspomnianych instytucji należy bez wątpienia Muzeum Historyczne Miasta Krakowa, które w latach 2016-2017 realizowało projekt „Miejsce Pamięci KL Plaszow”. Celem projektu było przeprowadzenie badań archeologicznych na terenie dawnego obozu koncentracyjnego oraz stworzenie formy upamiętnienia ofiar obozu ${ }^{20}$. Podczas badań odnaleziono zarówno pozostałości budynków obozowych, jak i kilkanaście tysięcy fragmentów przedmiotów związanych z historią obozu Plaszow. Wśród zabytków masowych są przede wszystkim gwoździe, łuski i pociski, fragmenty przedmiotów szklanych oraz przedmioty niezidentyfikowane. Wśród przedmiotów wydzielonych (zaledwie 7 procent ogółu) znajdują się głównie rzeczy osobiste (podobnie jak wśród obiektów

19 Ustawa z dnia 23 lipca 2003 r. o ochronie zabytków i opiece nad zabytkami (Dz.U. z 2003 r. Nr 162, poz. 1568).

20 M. Bednarek, K. Karski, M. Śmietana, op. cit., s. 11. 
odnalezionych w wykopaliskach pod POLIN), takie jak klucze, grzebienie czy inne przybory toaletowe ${ }^{21}$. Następstwem projektu „Miejsce Pamięci KL Plaszow" było wydzielenie samodzielnej instytucji muzeum, jaką stało się Miejsce Pamięci KL Plaszow w Krakowie działające od 1 stycznia 2021 r.

Badania wykopaliskowe prowadzone są na terenach należących do licznych muzeów, które powstały jako miejsca pamięci. Jako kolejny przykład mogą posłużyć pozostałe placówki muzealne utworzone w miejscach dawnych obozów koncentracyjnych, takie jak Muzeum Auschwitz-Birkenau, Muzeum Stutthof w Sztutowie, w Chełmnie nad Nerem czy w Sobiborze. Badania te często mają charakter badań ratowniczych, ponieważ relikty budynków oraz zabytków ruchomych ulegają stopniowej degradacji, zalegając w ziemi. Obiekty wydobyte podczas tego rodzaju badań trafiają zwykle do zbiorów instytucji znajdującej się na terenie objętym badaniami ${ }^{22}$.

Do innych niż POLIN muzeów trafiają także przypadkowe znaleziska archeologiczne. Tutaj warto wymieć chociażby tzw. Skarb z ulicy Fabrycznej, znajdujący się obecnie w zbiorach Muzeum Podlaskiego w Białymstoku. Do odkrycia doszło pod koniec lat dziewięćdziesiątych XX w. podczas prac budowlanych przy wznoszeniu szpitala Ministerstwa Spraw Wewnętrznych przy ul. Fabrycznej w Białymstoku, kiedy operator koparki natrafił na skrzynię znajdującą się w ziemi. W skrzyni znajdowały się przedmioty stanowiące dawniej zastawę stołową mieszczańskiego domu (platery, szklane i porcelanowe talerze, świeczniki), które właściciel zabezpieczył przed potłuczeniem, przekładając obiekty gazetami w języku jidysz. Na jednej z nich widoczna jest data - 1938 r. Miejsce odkrycia znajduje się u zbiegu ul. Fabrycznej i Ogrodowej, które w czasie drugiej wojny światowej znajdowały się w granicach getta. Zakopanie skrzyni stanowiło najprawdopodobniej próbę zachowania rodzinnej własności przed rekwizycją. W tym wypadku nie ma jednak wątpliwości odnośnie do proweniencji obiektów. O tym, że znalezisko stanowi mienie pożydowskie, świadczą zarówno gazety w języku jidysz, w które zapakowane były obiekty, jak i kontekst - obiekty znajdujące się w skrzyni zostały celowo zabezpieczone i ukryte na terenie dawnego getta żydowskiego ${ }^{23}$.

${ }^{21}$ K. KARSKI, op. cit., s. 35-36.

22 Ł. BANASZEK, Badania archeologiczne w ramach projektu „Sztutowo czy Stutthof?”, [w:] „Sztutowo czy Stutthof?" Oswajanie krajobrazu kulturowego, red. Ł. BANASZEK, M. WosiŃSKA, PoznańSztutowo 2011, s. 28.

${ }^{23}$ M. Karczewska, M. Karczewski, H. Karwowska, K. Rusin, U. Stankiewicz, A. WaWRUSIEWICZ, Archeologia Biategostoku, Białystok 2015, s. 69-70. 
Poza obiektami pozyskanymi podczas badań wykopaliskowych oraz nadzoru archeologicznego związanych z projektem budowy Muzeum Historii Żydów Polskich (1998 i 2009) w zbiorach muzeum znajdują się także przypadkowe znaleziska archeologiczne, które darczyńcy zebrali najczęściej spontanicznie w celu późniejszego przekazania do kolekcji POLIN.

\section{Podsumowanie}

Obie grupy obiektów opowiadają nam o losach w niezwykle sugestywny sposób (nadpalenia, uszkodzenia, zagięcia, korozja) o historii ludzi, którzy byli uwięzieni w getcie warszawskim. Wielu z nich zginęło lub straciło dorobek swojego życia w trakcie likwidacji getta, o czym świadczy zarówno raport z badań archeologicznych, jak i stan obiektów, które zostały podczas tych badań wydobyte i zaewidencjonowane. Obiekty znalezione przypadkowo nie mają żadnej dokumentacji, tak jak w wypadku badań archeologicznych. Zwykle pochodzą one z hałd ziemi powstałych podczas prac budowlanych lub bezpośrednio z wykopów pod rury lub fundamenty budynków współczesnego Muranowa. Nie ma zatem pewności, czy znalezione przez darczyńców fragmenty, mimo stanu przywodzącego na myśl przetrwanie likwidacji i pożaru getta warszawskiego (znamion nadpalenia, wgięcia), rzeczywiście pochodzą z gruzowiska getta. Mogły bowiem zostać przywiezione na ten teren spoza Warszawy - razem z piaskiem przeznaczonym do wyrównania terenów pod budowę bloków, które znajdują się tam obecnie.

W związku z posiadaniem dokumentacji dotyczącej znalezienia zabytku archeologicznego lub jej brakiem przekaz, jaki niosą ze sobą zabytki należące do dwóch wyróżnionych przeze mniegrupzabytków archeologicznych znajdujących się w zbiorach POLIN, jest zgoła odmienny. Obiekty znalezione podczas badań archeologicznych stawią dziś dokumentację życia i codzienności mieszkańców getta. W sposób niezwykle sugestywny opowiadają nam o ich tragicznych losach. Obiekty archeologiczne w większości nie pozwalają jednak muzealnikom na wydzielenie narracji dotyczących losów indywidualnych mieszkańców, jak w wypadku pamiątek przynoszonych przez rodziny. Zwykle brak bowiem informacji dotyczących ich dawnych właścicieli. Pojedynczy znaleziony w ziemi skorodowany klucz do drzwi czy połamana para szylkretowych okularów nie mają przecież żadnej etykiety mówiącej o tym, które drzwi dany klucz otwierał czy na czyim nosie okulary były noszone. Obiekty należy postrzegać jako swego 
rodzaju grupę. Jako grupa w sposób niezwykle sugestywny opowiadają jedną, wspólną dla mieszkańców getta historię. Historię Zagłady jego mieszkańców.

Przypadkowe znaleziska są dla nas - muzealników świadectwem pewnego zjawiska społecznego, jakim jest głęboka potrzeba zachowania pamięci o tym miejscu i ludziach, którzy tu zginęli, przez jego współczesnych mieszkańców. Owe obiekty opowiadają więc historię nie tyle mieszkańców getta, ile współczesnych mieszkańców dzielnicy, którzy stale pielęgnują pamięć o przeszłości tego miejsca.

Zarówno obiekty wydobyte z ziemi podczas badań archeologicznych, jak i te znalezione przypadkowo, stanowią swego rodzaju łącznik między współczesnymi mieszkańcami Muranowa a nieistniejącym już światem sprzed zburzenia getta warszawskiego, stanowią o „tożsamości” tego szczególnego miejsca. Zadaniem muzealników jest w tym kontekście przekazywanie kolejnym pokoleniom opowieści o minionych czasach za pomocą gromadzonych w muzealnych magazynach przedmiotów, udostępniania ich publiczności podczas wystaw muzealnych, za pośrednictwem strony internetowej, działalności edukacyjnej czy artykułów naukowych oraz popularyzatorskich.

\section{BIBLIOGRAFIA}

\section{Źródła drukowane}

Ustawa z dnia 23 lipca 2003 r. o ochronie zabytków i opiece nad zabytkami (Dz.U. z 2003 r. $\mathrm{Nr} 162$, poz. 1568).

\section{Opracowania}

Banaszek Ł., Badania archeologiczne w ramach projektu „Sztutowo czy Stutthof?”, [w:] „Sztutowo czy Stutthof?” Oswajanie krajobrazu kulturowego, red. Ł. Banaszek, M. Wosińska, Poznań-Sztutowo 2011, s. 27-33.

Bednarek M., Karski K., Śmietana M., Miejsce Pamięci KL Plaszow. Raportza okres 20162017, Kraków 2017.

Cędrowski R., Sprawozdanie z przeprowadzenia badań archeologicznych zwiąanych z budowa Muzeum Historii Żydów Polskich w Warszawie, Warszawa 2009.

Chomątowska B., Stacja Muranów, Wołowiec 2016. 
Dant T., Kultura materialna w rzeczywistości spotecznej. Wartości, dziatania, style życia, przekł. J. Barański, Kraków 2007.

Janus A., Romnik N., Projekt upamiętnienia kryjówki na cmentarzu żydowskim przy ul. Okopowej w Warszawie, Warszawa 2021.

Karczewska M., Karczewski M., Karwowska H., Rusin K., Stankiewicz U., Wawrusiewicz A., Archeologia Biategostoku, Białystok 2015.

Karski K., Kl Plaszow. Archeologia Miejsca Pamięci, Kraków 2019.

Karski K., Śmietana M., Muzeum - Archiwum Pamięci. Uwagi na temat roli materiatów archeologicznych w Muzeach - Archiwach Pamięci na przyktadzie KL Plaszow, „Folia Praehistorica Posnaniesia" 2009, t. 24, s. 289-308.

Milewska M., Kaniecki P., Archeologia o Muranowie, [w:] „Tu Muranów. Dzielnica pod gruzami”, red. K. Radecka-Mikulicz, Warszawa 2020.

Nowak-Radziejwoska H., Kaniecki P., Porcelana, [w:] „Przynoszęrzecz, przynoszę historię”, red. J. Pawlak, P. Kaniecki, Warszawa 2016.

Piątkowska R., Kaniecki P., Obiekty „muranowskie”, [w:] „Tu Muranów. Dzielnica pod gruzami", Warszawa 2020.

Radecka-Mikulicz K., Muranów - warstwy życia, warstwy pamięci, [w:] „Tu Muranów. Dzielnica pod gruzami”, red. K. Radecka-Mikulicz, Warszawa 2020.

\section{Netografia}

Historia: od Idei, przez OHEL do Muzeum POLIN, https://www.polin.pl/pl/about-the-museum/historia-od-idei-przez-ohel-do-muzeum-polin (dostęp: 20 X 2020).

\section{Marta Frączkiewicz}

\section{THE CITY AND THE WAR. ARCHAEOLOGICAL OBJECTS IN THE COLLECTION OF THE POLIN MUSEUM}

Summary. In the collection of the Museum of the History of Polish Jews in Warsaw, apart from works of art, historical memorabilia and Judaica, we can also find many archaeological exhibits. Some of these objects were collected during archeological research carried out in the area where the Museum is currently located in 1998 and 2009. The others are accidental finds. The aim of the article is both to show the specificity of the objects dug out of the rubble of the Warsaw Ghetto, and to try to convey the story that these objects tell us. Since we are not able to obtain information about the "biographies of things" excavated from the ground from their original owners, invaluable information about the history of the objects, as well as people to whom they formerly belonged, constitutes their state of preservation and the place where they were found. The archaeological exhibits discussed in the text testify to the life and everyday life of the ghetto inhabitants, while reminding us of their tragic fate.

Keywords: archeology, museology, Jews, World War II, Warsaw ghetto, museum exhibits 